Potentially Favorable Areas for Large-Yield Wells in the Red River Formation and Madison Limestone in Parts of Montana, North Dakota, South Dakota, and Wyoming

GEOLOGICAL SURVEY PROFESSIONAL PAPER 1273 -E 


\section{Potentially Favorable Areas for Large-Yield Wells in the Red River Formation and Madison Limestone in Parts of Montana, North Dakota, South Dakota, and Wyoming}

By L. M. MACCARY, E. M. CUSHING, and D. L. BROWN

GEOLOGY AND HYDROLOGY OF THE MADISON LIMESTONE AND ASSOCIATED ROCKS IN PARTS OF MONTANA, NEBRASKA, NORTH DAKOTA, SOUTH DAKOTA, AND WYOMING

GEOLOGICAL SURVEY PROFESSIONAL PAPER 127 3-E

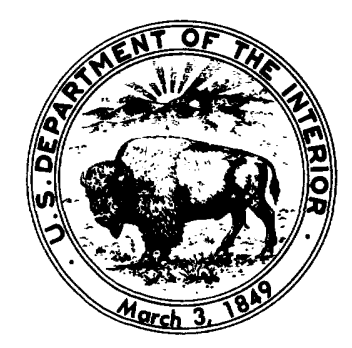




\section{UNITED STATES DEPARTMENT OF THE INTERIOR}

JAMES G. WATT, Secretary

GEOLOGICAL SURVEY

Dallas L. Peck, Director

MacCary, L. M. (Lawrence Mend), 1925-

Potentially favorable areas for large-yield wells in the Red River Formation and Madison Limestone in parts of Montana, North Dakota, South Dakota, and Wyoming.

(Geological Survey professional paper ; 1273-E

Bibliography: $p$.

Supt. of Docs. no.: I 19.16:1273E

1. Water, Underground-Middle West. 2. Wells-Middle West. 3. Geology, Stratigraphic-Paleozoic. I. Cushing, E. M. (Elliott Morse), 1914- II. Brown, D. L. (Dennis L.) III. Title. IV. Series.

GB1017.M3 1983 $551.49^{\prime} 0978 \quad 82-600377$

For sale by the Distribution Branch, U.S. Geological Survey, 604 South Pickett Street, Alexandria, VA 22304 


\section{CONTENTS}

$\begin{array}{lr}\text { Abstract } & \text { Page } \\ \text { Introduction } & \text { E1 } \\ \text { Acknowledgments } & 1 \\ \text { Method of evaluating areas } & 2 \\ \quad \text { Potentially favorable areas in the Red River Formation } & 4 \\ \quad \text { Potentially favorable areas in the Madison Limestone } & 4 \\ \quad \text { Potentially favorable areas in the combined Red River Formation and Madison } & 5 \\ \quad \text { Limestone -- } & 6 \\ \text { Comparison of areal evaluations with yield results } & 6 \\ \text { Other factors affecting well yield } \\ \text { Conclusions } \\ \text { References cited }\end{array}$

\section{ILLUSTRATIONS}

Figure 1. Map showing location of study area

2. Examples of lithology and well-log patterns of Madison Group marker units

3-14. Maps showing:

3. Potentially favorable areas for wells yielding more than $500 \mathrm{gal} / \mathrm{min}$ from the Red River Formation (Ordovician)

4. Areas where rocks with porosity equal to or greater than 10 percent are more than $100 \mathrm{ft}$ thick in the Red River Formation (Ordovician)

5. Areas where dolomite with an average grain size greater than $0.0625 \mathrm{~mm}$ is more than $100 \mathrm{ft}$ thick in the Red River Formation (Ordovician)

6. Geologic structures that may affect yield of wells

7. Areas of greater than $1 \mathrm{ohm}$-meter of apparent water resistivity (Rwa) in the Red River Formation (Ordovician)

8. Height to which water will rise in wells completed in the Red River Formation (Ordovician)

9. Potentially favorable areas for wells yielding more than $500 \mathrm{gal} / \mathrm{min}$ from the Madison Limestone (Mississippian)

10. Areas where rocks with porosity equal to or greater than 10 percent are more than $100 \mathrm{ft}$ thick in the Madison Limestone intervals M-3 to M-7 and M-7 to M-8.5 (Mississippian)

11. Areas where dolomite with an average grain size greater than $0.0625 \mathrm{~mm}$ is more than $100 \mathrm{ft}$ thick in the Madison Limestone interval M-7 to M-8.5 (Mississippian)

12. Areas of greater than $1 \mathrm{ohm}$-meter of apparent water resistivity (Rwa) in the Madison Limestone interval M-7 to M-8.5 (Mississippian)

13. Height to which water will rise in wells completed in the Madison Limestone (Mississippian)

14. Potentially favorable areas for wells yielding more than $500 \mathrm{gal} / \mathrm{min}$ from both the Red River Formation (Ordovician) and the Madison Limestone (Mississippian)

\section{TABLE}

TABLE 1. Generalized correlation chart of Paleozoic rocks [in pocket] 


\section{METRIC CONVERSION TABLE}

[Inch-pound units in this report may be converted to metric (SI) units by using the following conversion factors:]

$\begin{array}{lcl}\text { Multiply inch-pound units } & B y & \text { To obtain metric units } \\ \text { inch } & 25.40 & \text { millimeter }(\mathrm{mm}) \\ \text { foot }(\mathrm{ft}) & 0.3048 & \text { meter } \\ \text { mile } & 1.609 & \text { kilometer } \\ \text { square mile }\left(\mathrm{mi}^{2}\right) & 2.590 & \text { square kilometer } \\ \text { gallon per minute (gal/min) } & 3.785 & \text { liter per minute }\end{array}$

Temperature is reported in degrees Fahrenheit $\left({ }^{\circ} \mathrm{F}\right)$. To convert degrees

Fahrenheit to degrees Celsius use

Temperature ${ }^{\circ} \mathrm{C}=\frac{\left(\text { Temperature }{ }^{\circ} \mathrm{F}-32\right)}{1.8}$ 


\title{
POTENTIALLY FAVORABLE AREAS FOR LARGE-YIELD WELLS IN THE RED RIVER FORMATION AND MADISON LIMESTONE IN PARTS OF MONTANA, NORTH DAKOTA, SOUTH DAKOTA, AND WYOMING
}

\author{
By L. M. MaCCary, E. M. Cushing, and D. L. Brown
}

\begin{abstract}
The need for large quantities of energy has created interest in the Fort Union coal region of the Northern Great Plains. Extensive development of this coal, which may include onsite steampower generation, gasification, liquefaction, and slurry-pipeline transport of the coal from this region, would place a significant demand on the region's limited steamflow. Aquifers in the Paleozoic rocks that underlie the Fort Union coal region, including the Red River Formation and the Madison Limestone, might supply, at least on a temporary basis, a significant part of the water required for coal development. The area of study encompasses approximatley 200,000 square miles, and includes eastern Montana, western North Dakota and South Dakota, northeastern Wyoming, and northwestern Nebraska.

This report, one of a series in the Madison Limestone study, uses hydrologic and geologic data to outline potentially favorable areas for well construction-that is, areas in which there is a good probability that large-yield wells (more than 500 gallons per minute) can be completed in the Red River Formation and in the Madison Limestone. Potentially favorable areas in terms of aquifer characteristics, for both the Red River Formation and the Madison Limestone, are given a numerical evaluation from 1 to 3 based on the number of the following criteria that are met: (1) The presence of relatively porous rock more than 100 feet thick, (2) the presence of dolomite more than 100 feet thick, and (3) the presence of known geologic structures that could affect yield. Areas rated 3 are those in which all three criteria are met; areas rated 2 are those in which two criteria are met; and areas rated 1 are those in which only one criterion is met. The criteria selected for this analysis were chosen because they can be recognized and mapped throughout the entire study area. Local features such as minor structures, solution zones, and rock facies of small extent were not included in this regional evaluation. In addition, water quality was considered in a general way in defining the favorable areas, by excluding areas in which the electrical resistivity of formation water, as calculated from geophysical well logs, was less than $1 \mathrm{ohm}$-meter. The numerical scales of the Red River Formation and Madison Limestone are summed to show potentially favorable areas for the combined aquifers. Certain additional factors that may be important to a prospective water user were not included in the numerical ranking-these include depths to the two aquifers, calcite saturation, water temperature, dissolvedsolids concentrations, and potentiometric head in relation to land surface. For a complete evaluation, potential users need to consider these factors plus local structures, facies, and solution zones in conjunction with the numerical rankings reflecting aquifer characteristics. To facilitate consideration of potentiometric head, maps are included in this report showing areas in which the potentiometric head is within certain ranges with respect to land surface.
\end{abstract}

\section{INTRODUCTION}

Energy needs have caused government and industry to focus attention on the Fort Union coal region of the Northern Great Plains, where a major part of the United States' coal reserves occur (fig. 1). Extensive development of this coal, which may include onsite steampower generation, gasification, liquefaction, and slurrypipeline transport, could place a significant demand on the region's limited water resources.

Steamflow in the region is unevenly distributed. Where steamflow is not already appropriated, development would require storage reservoirs and distribution systems; where it already is fully appropriated, its use would deprive present users of their supply.

Paleozoic rocks, which include the Madison Limestone, its equivalents, and associated rocks, underlie the Fort Union coal region and adjacent areas in Montana, North Dakota, South Dakota, and Wyoming. Aquifers in these rocks, including the Red River Formation and the Madison Limestone, might supply, at least on a temporary basis, a significant part of the water required for coal development.

The purpose of the Madison Limestone Project, begun during 1976, was to evaluate the quantity and quality of water in rocks of Paleozoic age. The project area encompasses approximately $200,000 \mathrm{mi}^{2}$ in eastern Montana, western North Dakota and South Dakota, northwestern Nebraska, and northeastern Wyoming (fig. 1). The area of greatest interest, however, is the Powder River basin of Montana and Wyoming, the area surrounding the Black Hills in South Dakota and Wyoming, and the adjacent areas in Montana and North Dakota. Throughout much of the project area, particularly in the Williston basin, rocks of Paleozoic age lie at such great depths that few water wells are drilled. The Madison Limestone crops out in the mountainous areas; however, in much of the region, it ranges in depth from 2,000 to $16,000 \mathrm{ft}$ below land surface. 


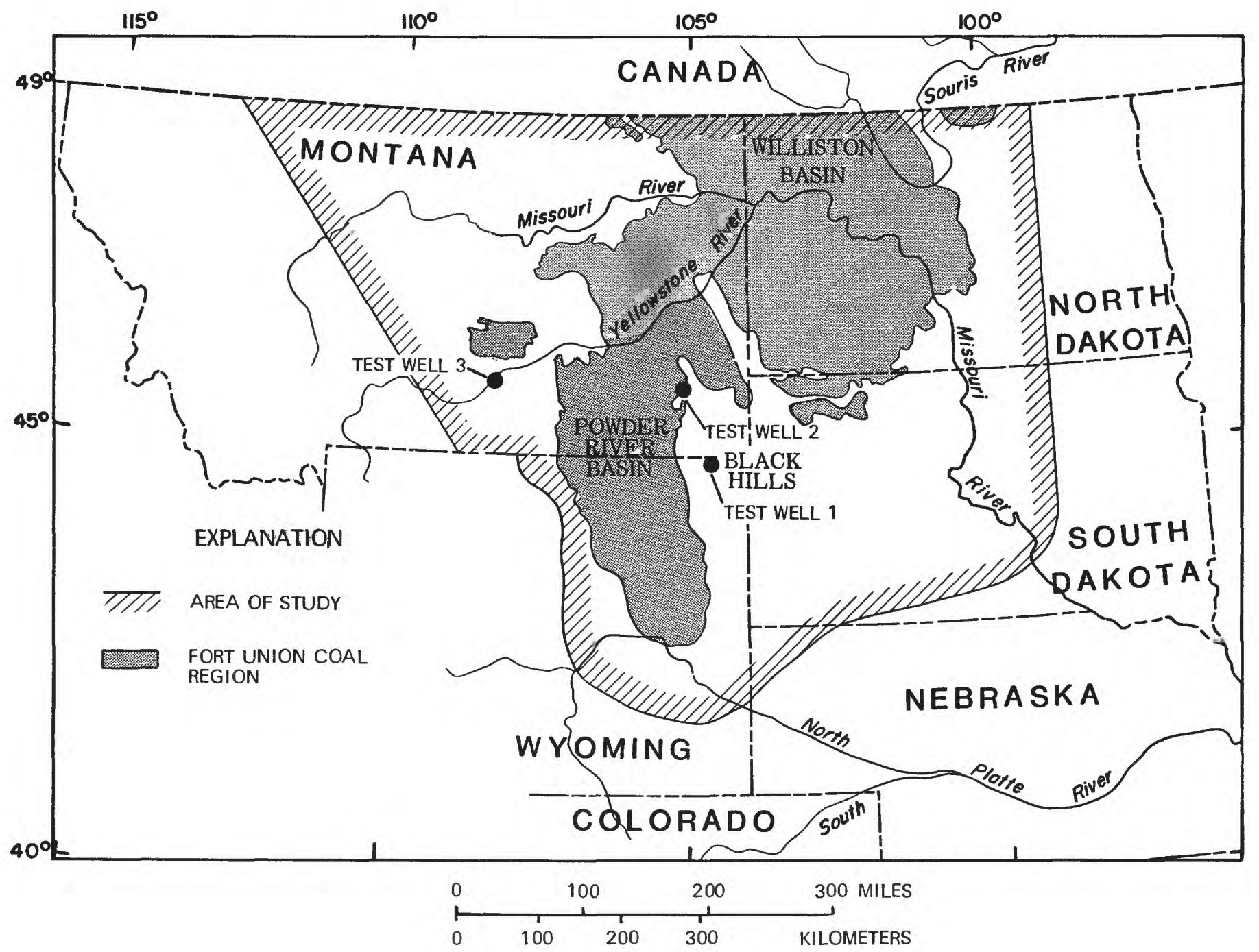

Figure 1.-Location of study area.

The purpose of this report is to summarize and present geologic and hydrologic information that outlines areas that are potentially favorable for obtaining large-yield (more than $500 \mathrm{gal} / \mathrm{min}$ ) wells in the Red River Formation and Madison Limestone.

The Madison Limestone is undivided in parts of the project area. Where it is divided into formations, it is called the Madison Group (table 1, in pocket). For consistency, however, the term Madison Limestone is used in this report in reference to all areas, even those in which the subdivision into formations has been recognized. During the Madison Limestone Project, marker beds that could be identified on geophysical logs were used to divide the Madison into time-stratigraphic units (fig. 2) (Peterson, 1981). Two of these units, termed the M-3 to M-7 and the M-7 to M-8.5, were used in the analysis described in this report. Thus, the thicknesses of porous sediment reported herein for the Madison Limestone are actually the total thicknesses within these two intervals, and the term Madison Limestone, as used in this discussion of potentially favorable areas, refers specifically to the $\mathrm{M}-3$ to $\mathrm{M}-7$ and $\mathrm{M}-7$ to $\mathrm{M}-8.5$ time-stratigraphic units.

\section{ACKNOWLEDGMENTS}

The study of the Madison Limestone and related rocks was conducted jointly by personnel of the U.S. Geological Survey in the Central Region and in the district offices of Montana, North Dakota, South Dakota, and Wyoming. This report uses the subsurface geology and correlations made by Donald L. Brown, and the markerbed correlations established by James A. Peterson. 


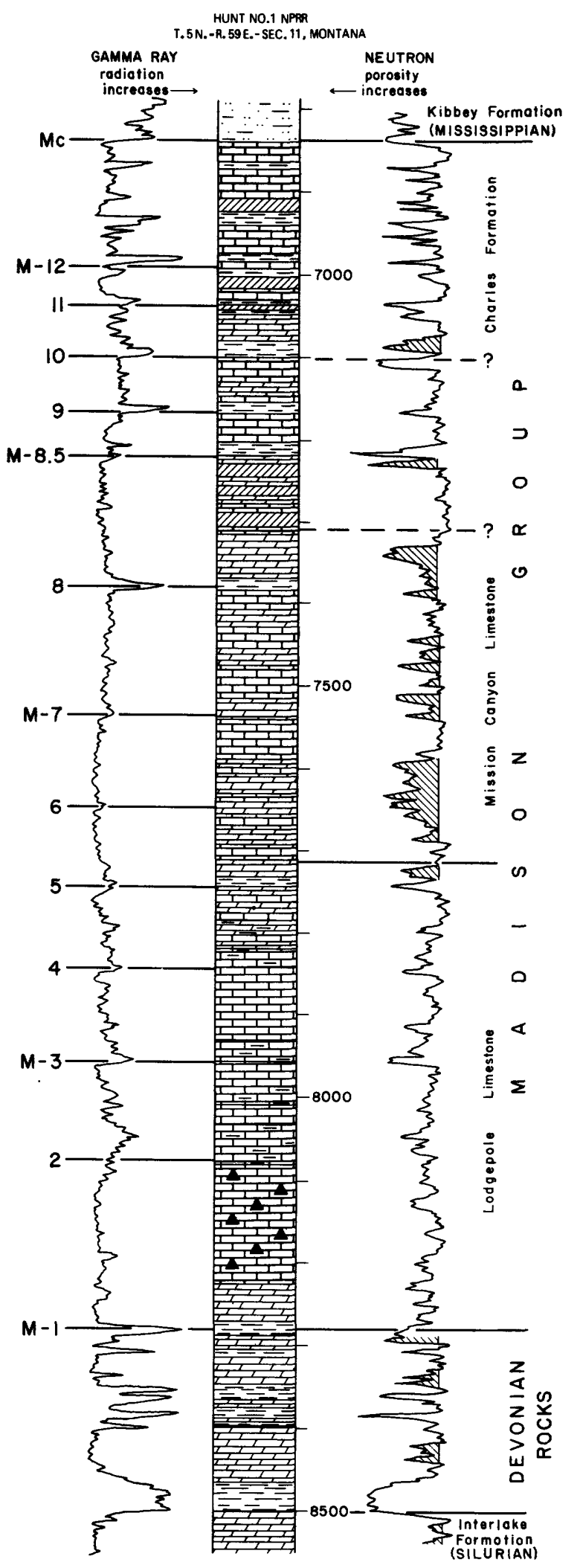

EXPLANATION

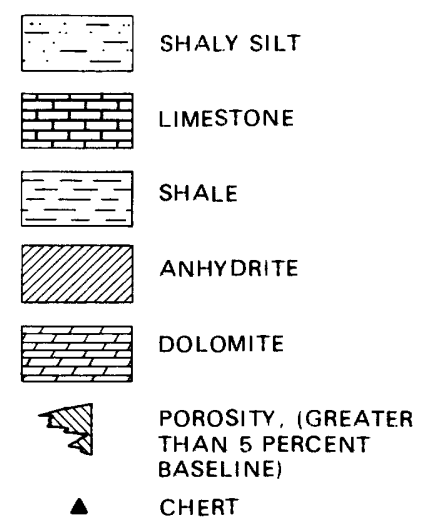

FIGURE 2.-Examples of lithology and well-log patterns of Madison Group marker units. 


\section{METHOD OF EVALUATING AREAS}

Areas in which aquifer characteristics are potentially favorable for the construction of large-yield wells (more than $500 \mathrm{gal} / \mathrm{min}$ ) in both the Red River Formation and the Madison Limestone were determined by delineating areas in which the apparent resistivity of the formation water, as calculated from geophysical well logs, is greater than $1 \mathrm{ohm}$-meter, and in which one or more of three geologic criteria are met. These areas were given numerical ranking on a scale from 1 to 3 . Areas of scale 3 are those in which all three criteria are met; areas of scale 2 are those in which two criteria are met; and areas of scale 1 are those in which only one criterion is met. The potentially favorable areas for the combined Red River Formation and Madison Limestone were determined by summing their respective rankings in their areas of overlap.

The three criteria used in the evaluation were (1) the presence of rocks with porosity, as indicated by electriclog analyses, equal to or greater than 10 percent and with a thickness greater than $100 \mathrm{ft}$; (2) the presence of dolomite with an average grain size greater than 0.0625 $\mathrm{mm}$ and with a thickness greater than $100 \mathrm{ft}$; and (3) the presence of geologic structures that could cause greater secondary permeability, and, therefore, larger well yields.

Thickness of porous rocks was used as a criterion for the selection of large-yield areas, because there is a good correlation between increasing porosity and increasing well yield in the Red River and Madison carbonate rocks. Thickness of dolomite was used as a criterion because crystalline dolomites with an average grain size larger than $0.0625 \mathrm{~mm}$ generally have relatively large porosities and permeabilities (Thayer, 1981). Geologic structures were used as the third criterion, although the way they affect yield may differ from one place to another. Only detailed studies along each structure will reveal whether the structure actually contributes to an increase in secondary permeability and well yield. However, for purposes of this anaylsis, geologic structures were assumed to increase the potential for large yields. Local geologic structures and solution zones, which may be important controls at specific sites, were not included in this regional study.

Other factors that a prospective water user may wish to consider, but which were not used in the numerical ranking, include depths to the two aquifers, calcite saturation of water, water temperature, relation of potentiometric head to the land surface, development of localized karst, and concentration of dissolved solids in the water. Maps relating to two of these factors, potentiometric head and dissolved-solids concentrations, are included in this report.
Dissolved-solids concentrations can be determined approximately on the basis of the apparent electrical resistivity of formation water by analyses of geophysical well logs. The general relationship between dissolvedsolids concentrations and apparent resistivity of formation water has been recognized for many years and is discussed more fully in a companion report (MacCary, 1981). An apparent formation water resistivity of 1 ohm-meter corresponds to a sodium chloride solution of approximately $5,500 \mathrm{mg} / \mathrm{L}$ (milligrams per liter) concentration. Although ions other than sodium and chloride are present in the formation water, an apparent resistivity of $1 \mathrm{ohm}$-meter or less was taken as indicative of unacceptably large dissolved-solids concentrations for the purpose of this report, and areas with apparent water resistivity of $1 \mathrm{ohm}$-meter or less were excluded from the potentially favorable areas for well development.

Maps of areas in which the apparent formation water resistivity is $1 \mathrm{ohm}$-meter or more are included for the Madison Limestone and for the Red River Formation. Outside these areas, the water generally is too mineralized for most uses; within these areas, its suitability depends upon the local dissolved-solids concentrations and the intended use of the water. Maps of apparent formation water resistivity (MacCary, 1981) may be used to provide further resolution in these areas.

The relationship between the altitude to which water can rise in a well and land-surface altitude determines whether or not the well will flow and in conjunction with aquifer properties, determines the rate of flow. A potentiometric head higher than the land surface indicates sufficient pressure available to produce flow and in general means a larger yield from the well, other factors being equal. Maps showing the relationship of potentiometric head to land surface, in an approximate sense, are included in this report. These may be used to delineate favorable areas in terms of the potential for obtaining flowing wells or for obtaining larger yields from pumped wells without excessive pumping lifts.

\section{POTENTIALLY FAVORABLE AREAS IN THE RED RIVER FORMATION}

Potentially favorable areas for the development of large-yield wells in the Red River Formation determined on the basis of aquifer characteristics, but limited to areas in which apparent water resistivity is greater than $1 \mathrm{ohm}$-meter, are shown in figure 3 , which is a composite of three maps that correspond to the three individual criteria used in the numerical ranking. These three maps are shown individually in figures 4,5 , and 6 . Areas where rocks with porosity equal to or greater than 10 percent are more than $100 \mathrm{ft}$ thick are shown in figure 4; 


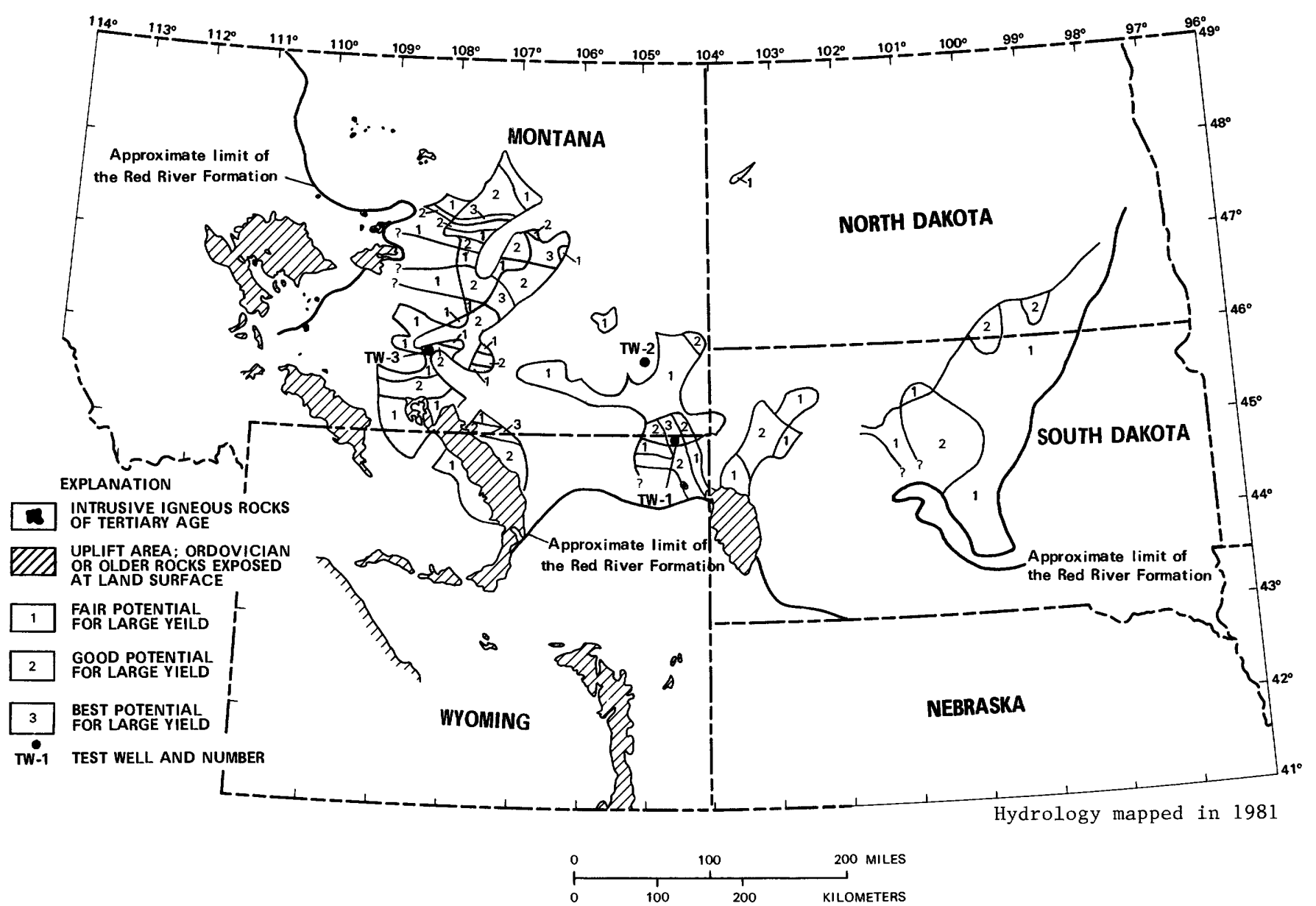

Figure 3. - Potentially favorable areas for wells yielding more than $500 \mathrm{gal} / \mathrm{min}$ from the Red River Formation (Ordovician).

areas where dolomite with an average grain size greater than $0.0625 \mathrm{~mm}$ is more than $100 \mathrm{ft}$ thick are shown in figure 5; and areas where there are geologic structures that may increase well yields are shown in figure 6.

Areas in the Red River Formation where the apparent resistivity of formation water, $R w a$, is greater than 1 ohm-meter are shown in figure 7. Within these areas, water of acceptable chemical quality may be available, depending on local conditions and the intended use of the water.

Ranges in the altitude of the potentiometric surface in the Red River Formation, relative to land surface, are shown in figure 8 , which was derived from a map by Miller and Strausz (1980a) and from land-surface altitudes. This map denotes favorable areas in terms of the possibility of flowing wells, and in terms of minimizing pumping lifts.

\section{POTENTIALLY FAVORABLE AREAS IN THE MADISON LIMESTONE}

The potentially favorable areas for large-yield wells in the Madison Limestone determined on the basis of aquifer characteristics, but limited to areas in which apparent water resistivity is greater than $1 \mathrm{ohm}$-meter, are shown in figure 9, which is a composite of three maps that correspond to the individual criteria as follows: (1) more than $100 \mathrm{ft}$ of rock with greater than 10 percent porosity in Madison Limestone intervals M-3 to M-7 and M-7 to M-8.5 (fig. 10); (2) more than $100 \mathrm{ft}$ of dolomite having an average grain size larger than $0.0625 \mathrm{~mm}$ in Madison Limestone interval M-7 to M-8.5 (fig. 11); and (3) occurrence of geologic structures that may affect well yields (fig. 6).

Areas in the Madison Limestone where the apparent resistivity of the formation water is $1 \mathrm{ohm}$-meter or more are shown in figure 12. As for the Red River Formation, this map indicates areas where water of acceptable chemical quality may be available depending on local conditions and the intended use of the water. Ranges in the height to which water will rise in wells completed in the Madison Limestone relative to land surface are shown in figure 13. This map was derived from a map by Miller and Strausz (1980b) and from landsurface altitudes. 


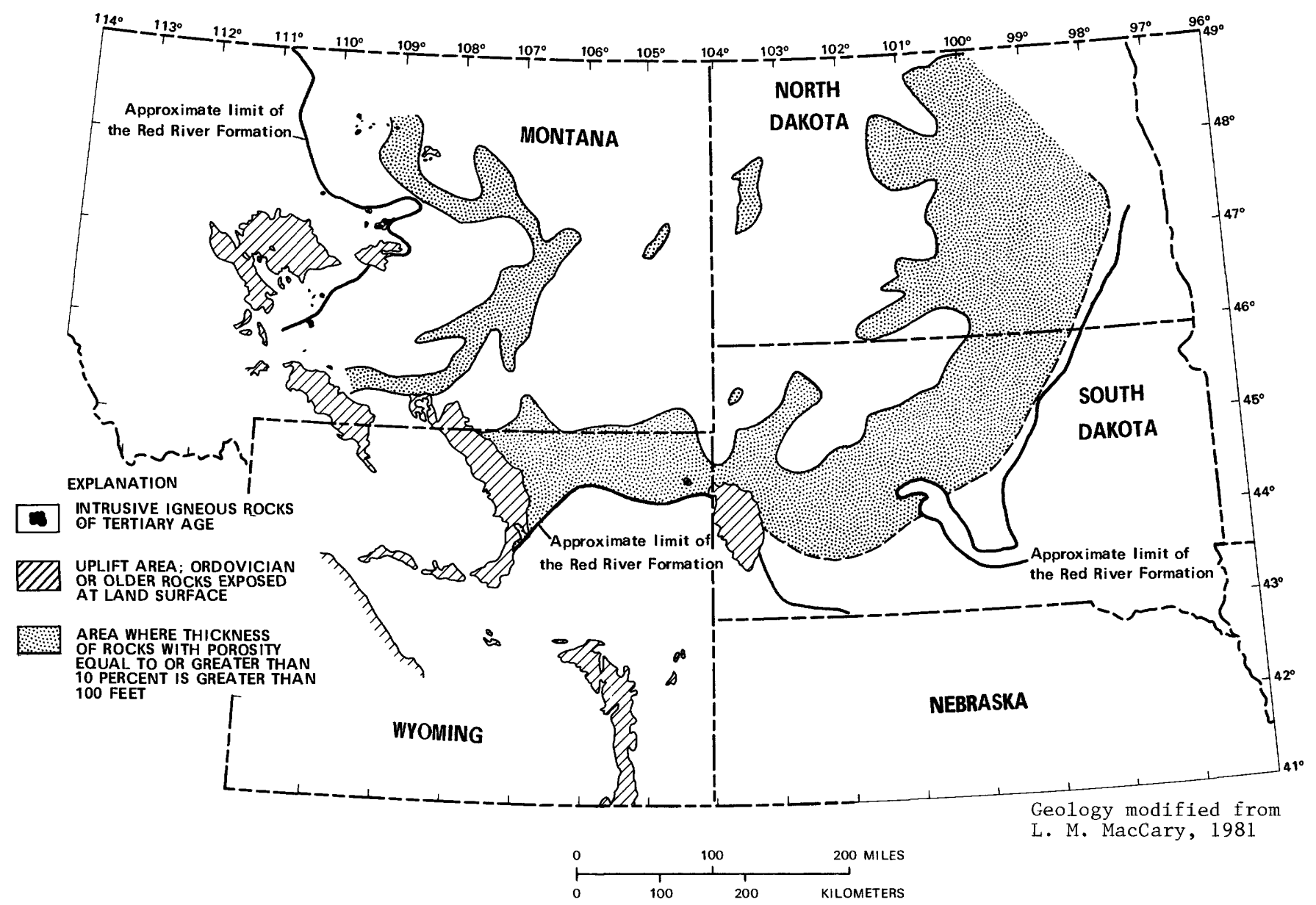

FIgURE 4.-Areas where rocks with porosity equal to or greater than 10 percent are more than $100 \mathrm{ft}$ thick in the Red River Formation (Ordovician).

POTENTIALLY FAVORABLE AREAS IN THE COMBINED RED RIVER FORMATION AND MADISON LIMESTONE

A combined map for the Madison Limestone and the Red River Formation, showing potentially favorable areas for the development of ground-water supplies, on the basis of the apparent water-resistivity criterion, and the three criteria relating to aquifer properties is shown in figure 14. In constructing figure 14, only areas of overlap between the potentially favorable areas shown in figures 3 and 9 were included. The numerical rankings from 2 to 6 were obtained by summing the rankings indicated on figures 3 and 9 for those areas of overlap.

\section{COMPARISON OF AREAL EVALUATIONS WITH YIELD RESULTS}

An empirical evaluation of figures 3,9 , and 14 was made by examining the results of the three test wells drilled in the Madison Limestone by the U.S. Geological Survey. Test well 1 is an area designated 3 for the Red River Formation, 1 for the Madison Limestone, and 4 for the two combined. The yield from test well 1 probably would be 650 to $700 \mathrm{gal} / \mathrm{min}$ if the well were allowed to flow freely (Blankennagel and others, 1977). Wellhead valving prevented flowing the well at more than $520 \mathrm{gal} / \mathrm{min}$. Velocity surveys in the wellbore indicated that about 70 percent of the yield is from the Red River Formation; the remainder is from the Madison Limestone. The well was not developed by acid fracturing. Drill-stem tests completed in the Red River Formation indicate that water in tightly cased wells will rise $99 \mathrm{ft}$ above land surface. Drill-stem tests in the Madison Limestone indicate that water in wells that are tightly cased will rise 97 feet above land surface at this site.

Test well 2 was drilled in a location that lies outside the favorable areas shown on all three maps (figs. 3, 9, and 14). The flow from the combined Madison Limestone and Red River Formation was about $44 \mathrm{gal} / \mathrm{min}$ (Brown and others, 1977). This well was drilled to test geologic and hydrologic theories, and the yield was not expected to be large. Drill-stem tests show that the potentiometric head of the Red River Formation is 


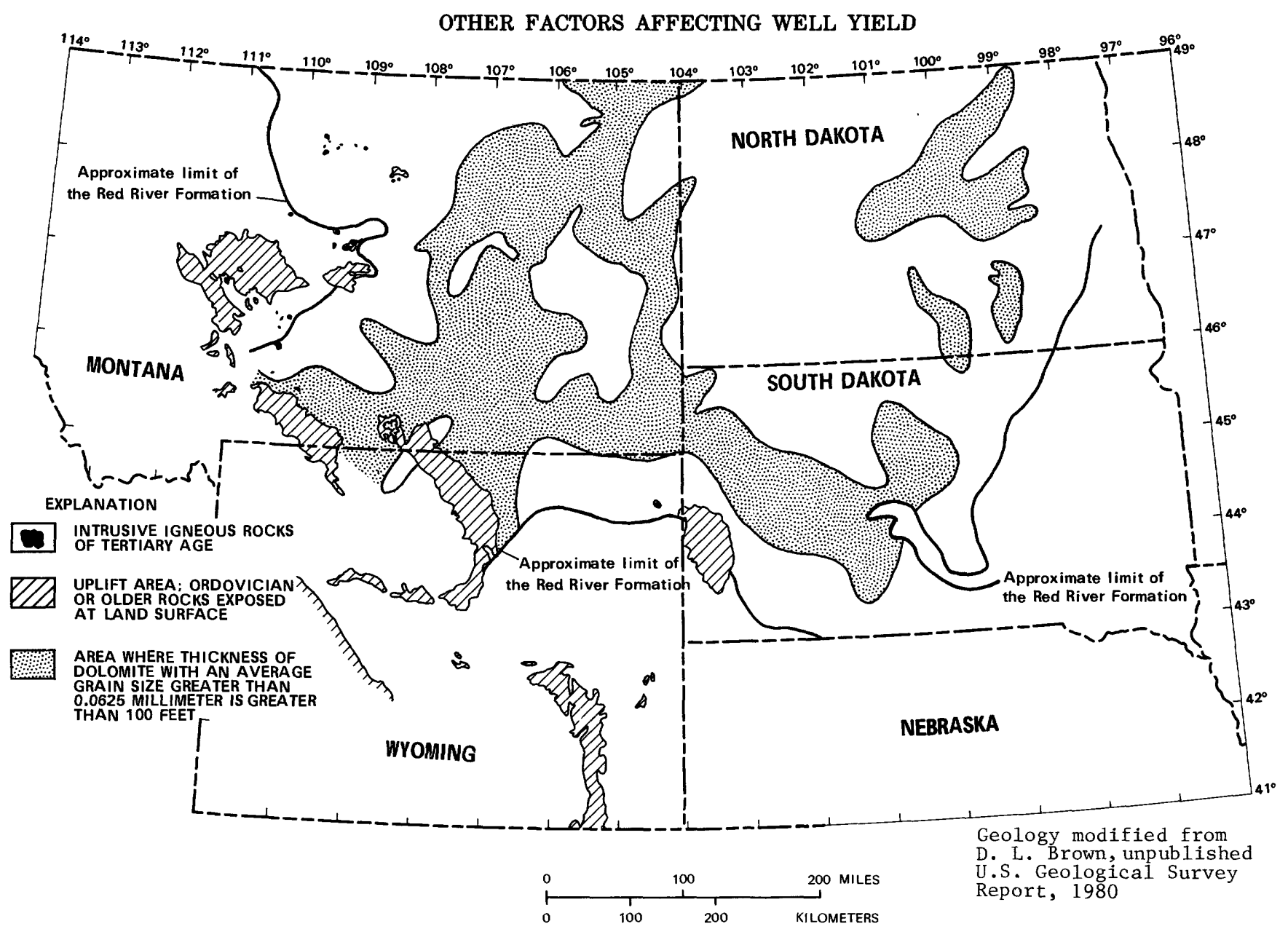

Figure 5. - Areas where dolomite with an average grain size greater than $0.0625 \mathrm{~mm}$ is more than $100 \mathrm{ft}$ thick in the Red River Formation (Ordovician).

$770 \mathrm{ft}$ above land surface at this site, while that of the Madison Limestone is $802 \mathrm{ft}$ above land surface.

Test well 3 was drilled in an area shown as 2 for the Red River Formation, 3 for the Madison Limestone, and 5 for the combined formations. Fracture porosity and enhanced permeability were expected at this site because of the proximity of the Lake Basin fault. During a drill-stem test of the Red River Formation, the potentiometric head was measured at $1,024 \mathrm{ft}$ above land surface and the flow was about $50 \mathrm{gal} / \mathrm{min}$ (Blankennagel and others, 1979). The water from this formation has a dissolved-solids concentration of about $4,000 \mathrm{mg} / \mathrm{L}$, which was too large to permit its discharge into the Yellowstone River. For this reason, only a limited test was performed on the Red River Formation. Also, because of water-quality considerations, only two zones in the Madison Limestone were completed in test well 3. The combined yield from these two zones was about 90 $\mathrm{gal} / \mathrm{min}$. The relatively small yield indicated that if fracture permeability were present at this site, the voids might have been partly filled by precipitation of second- ary calcite and evaporate minerals. The well was acidized and fractured hydraulically to dissolve secondary minerals and to intercept open fracture zones in the immediate vicinity. Preliminary evaluation, based on a 48-hour flow test, indicates that the combined yield from the two zones in the Madison Limestone increased to about 2,380 gal/min (R. K. Blankennagel, oral commun., 1980). Drill-stem tests showed that the potentiometric head of the Madison Limestone at this site is $1,038 \mathrm{ft}$ above land surface.

\section{OTHER FACTORS AFFECTING WELL YIELD}

Several additional factors that might affect the economics of ground-water development were not considered in this analysis. Depth of the aquifer below land surface commonly is an economic deterrent to the drilling of wells. The Red River Formation, for example, ranges in depth from about $2,000 \mathrm{ft}$ below land surface in the potentially favorable area at the northern end of the Black Hills, to more than $9,000 \mathrm{ft}$ deep in the 


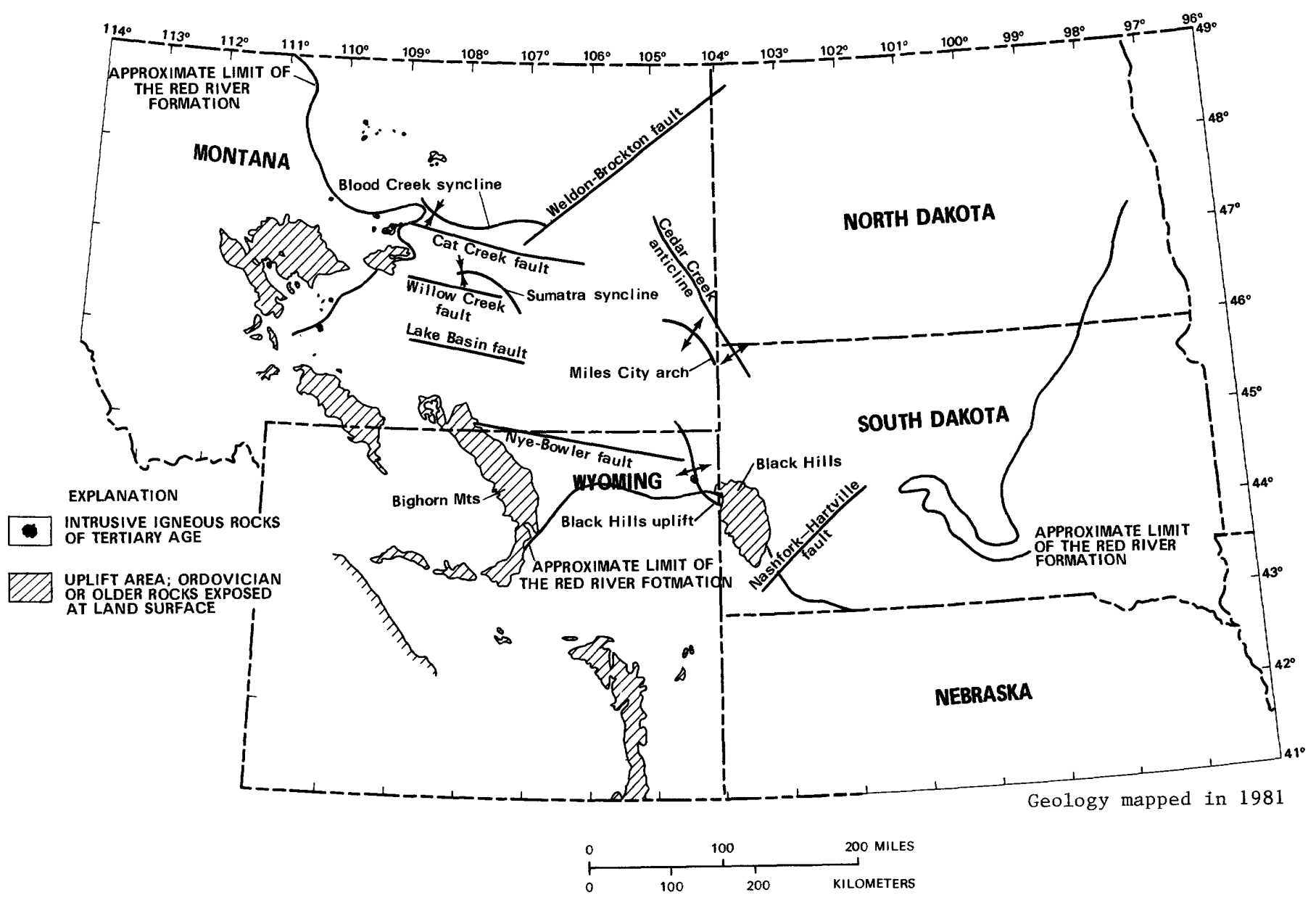

FiguRe 6. -Geologic structures that may affect yield of wells.

favorable area near the common borders of Montana, North Dakota, and South Dakota.

As noted previously, the $1 \mathrm{ohm}$-meter criterion for apparent resistivity of formation water serves only to exclude excessively mineralized water. If relatively fresh water is needed, it can be found only in restricted parts of the favorable areas shown in figures 3, 9, and 14. For the Red River Formation these parts would include areas in Wyoming at the northern end of the Black Hills and areas in Wyoming and Montana at the northwestern end of the Bighorn Mountains. For the Madison Limestone they would include areas in Wyoming and Montana at the northeastern end of the Bighorn Mountains.

In much of the project area, waters in the Red River Formation and Madison Limestone are supersaturated with respect to both calcite and carbon dioxide. The degree of this supersaturation increases with temperature. Consequently, as these waters, especially if they are hot $\left(140^{\circ} \mathrm{F}\right.$ or more), move into areas where pressure decreases, such as along a geologic structure or near a pumped or flowing well, carbon dioxide is released; this in turn may cause calcite to precipitate in the pores and fractures. This precipitation of calcite may have two significant results: (1) Well yields may not be as large as expected, and (2) well yields may decrease with time because of fracture sealing. Both of the above problems sometimes can be alleviated by acidizing and fracturing the water-bearing zones penetrated by the well.

A final criterion that may have to be considered in some instances is the temperature of the water. The temperature of ground water increases with depth of the formation; it is hottest in the deep basins and coolest in the recharge areas. Temperatures in the Madison Limestone range from less than $100^{\circ} \mathrm{F}$ in the areas east of the Black Hills to approximately $200^{\circ} \mathrm{F}$ in the area east of the Bighorn Mountains in Wyoming. Temperatures in the Red River Formation range from less than $100^{\circ} \mathrm{F}$ at the northern end of the Black Hills, to more than $220^{\circ} \mathrm{F}$ in the area east of the Bighorn Mountains in Wyoming. 


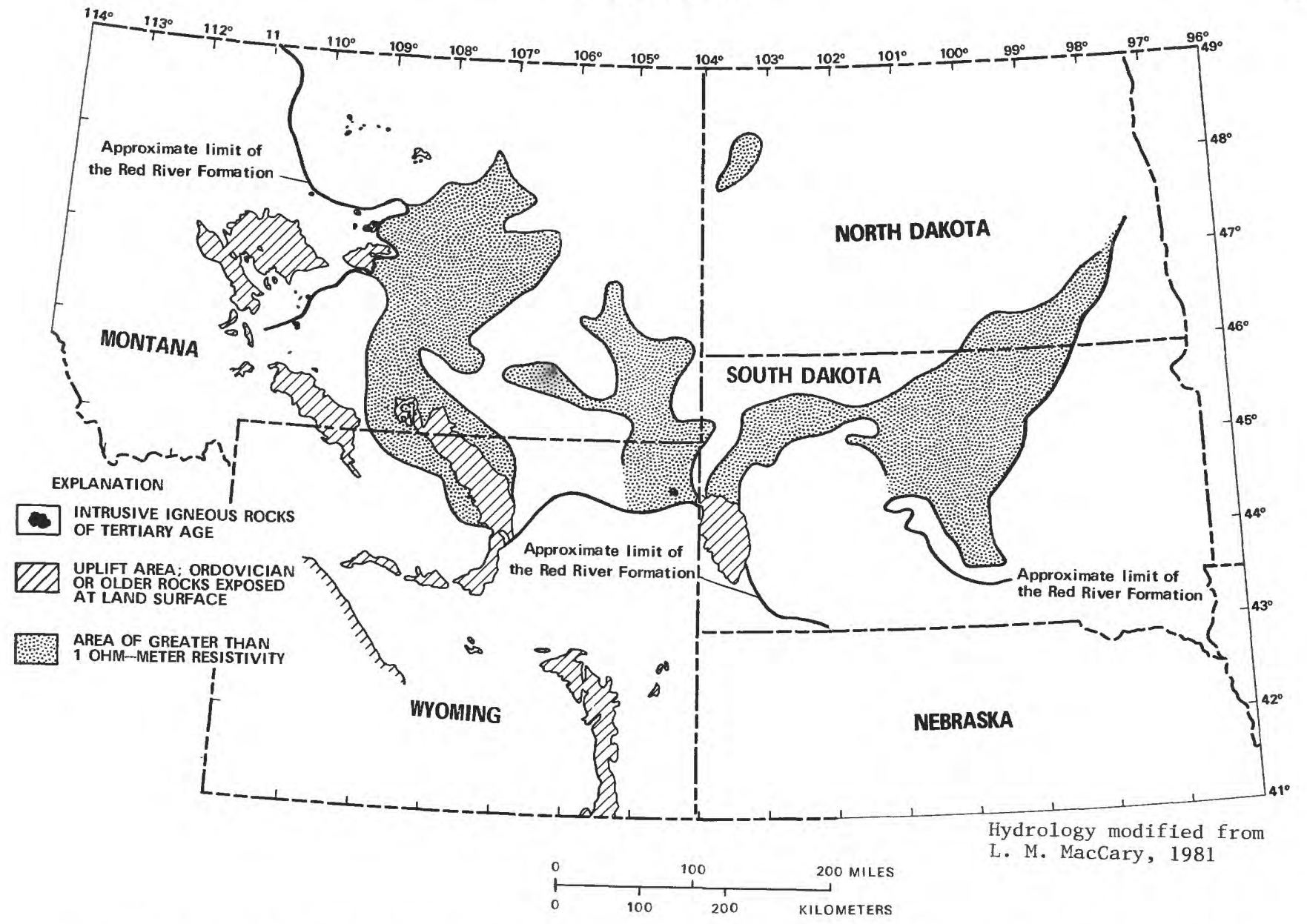

FIGURE 7. - Areas of greater than $1 \mathrm{ohm}$-meter of apparent water resistivity (Rwa) in the Red River Formation (Ordovician).

\section{CONCLUSIONS}

Potentially favorable areas for large-yield wells (more than $500 \mathrm{gal} / \mathrm{min}$ ) in the Red River Formation and the Madison Limestone were determined by overlaying various geologic and hydrologic maps and delineating those areas where apparent formation water resistivity is greater than 1 ohm-meter and where selected lithologic criteria were met. For the lithologic criteria, the areas were given a numerical scale depending on the number of criteria that were met. The apparent electrical resistivity of formation water was used to identify areas in which water quality may be acceptable for some uses; maps showing ranges in potentiometric head relative to land surface were used to evaluate the poten- tial for flowing wells. These two factors were not included in the numerical ranking, except for the exclusion of areas in which resistivity is less than $1 \mathrm{ohm}$-meter. Potentially significant factors that were not considered at all in this analysis include depth of formation, degree of calcite saturation, water temperature, presence of local geologic structures and solution zones, and greater resolution with regard to water quality than that provided by the $1 \mathrm{ohm}$-meter criterion.

The Red River Formation and the Madison Limestone, in parts of the potentially favorable areas, contain water of marginal quality. If relatively fresh water is needed, consideration could be restricted to areas where the apparent resistivity of formation water is $10 \mathrm{ohm}$ meters or greater. 


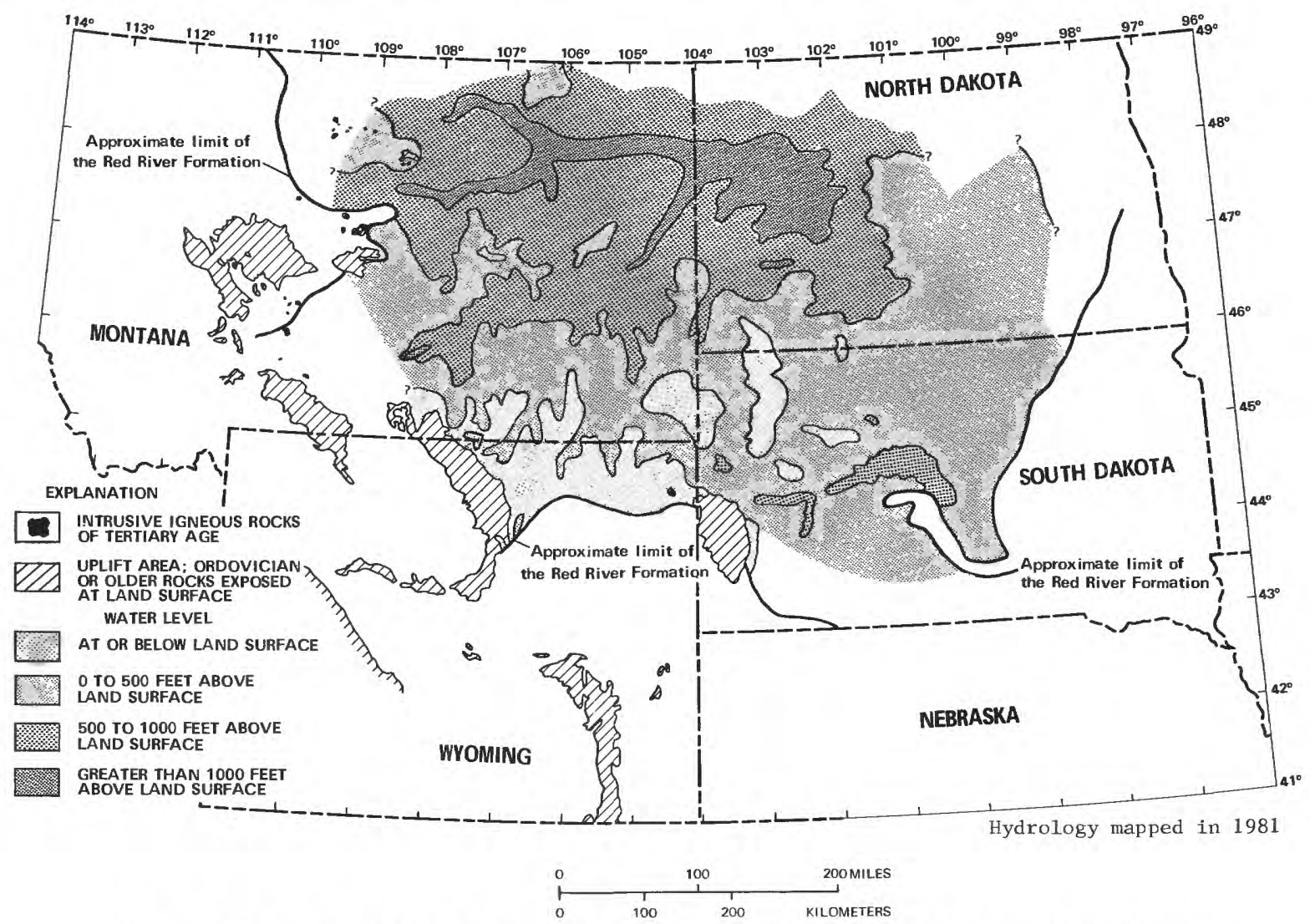

FIGURE 8. - Height to which water will rise in wells completed in the Red River Formation (Ordovician).

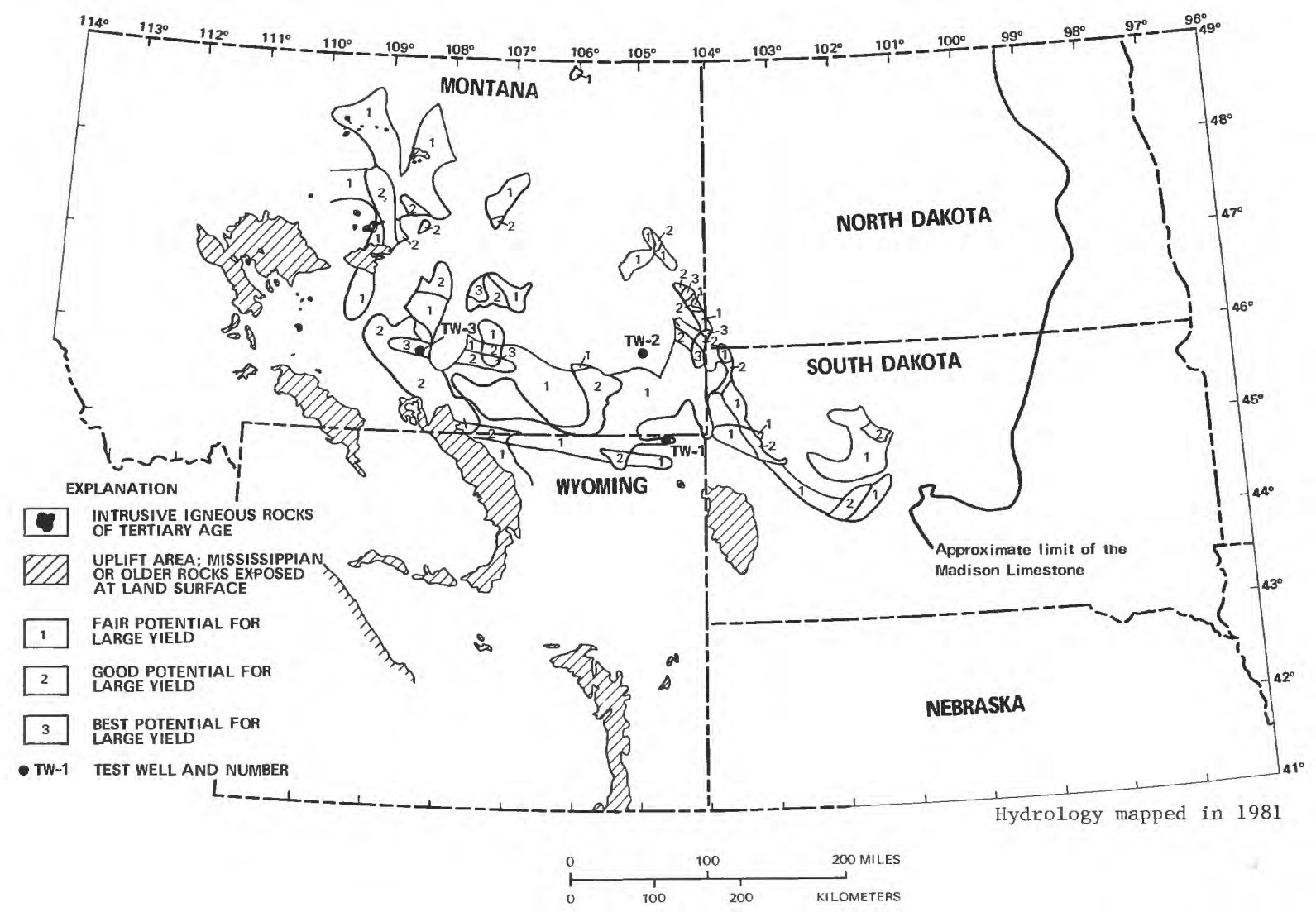

FIGURE 9. - Potentially favorable areas for wells yielding more than $500 \mathrm{gal} / \mathrm{min}$ from the Madison Limestone (Mississippian). 


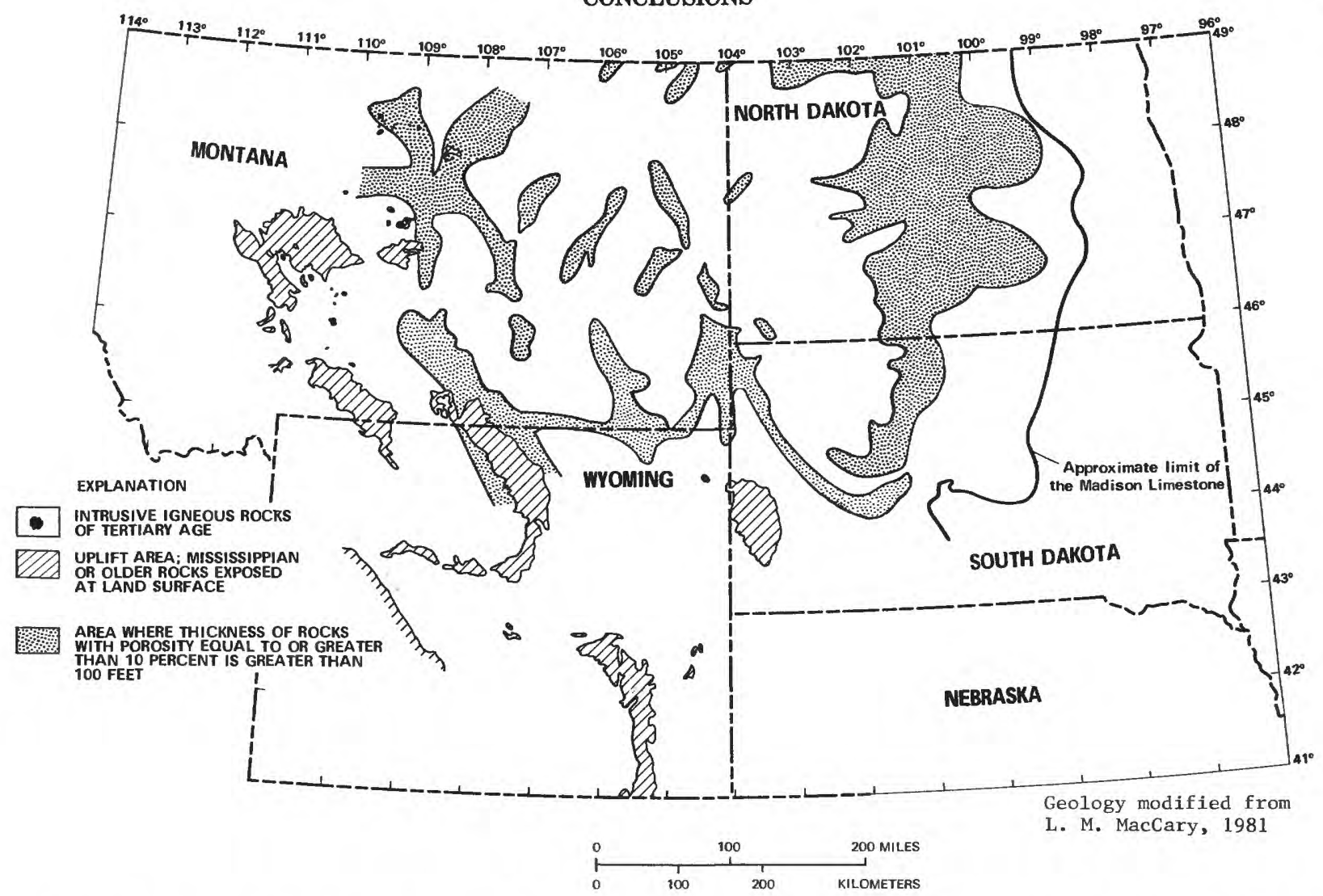

FiguRE 10.-Areas where rocks with porosity equal to or greater than 10 percent are more than $100 \mathrm{ft}$ thick in the Madison Limestone intervals $\mathrm{M}-3$ to $\mathrm{M}-7$ and $\mathrm{M}-7$ to $\mathrm{M}-8.5$ (Mississippian).

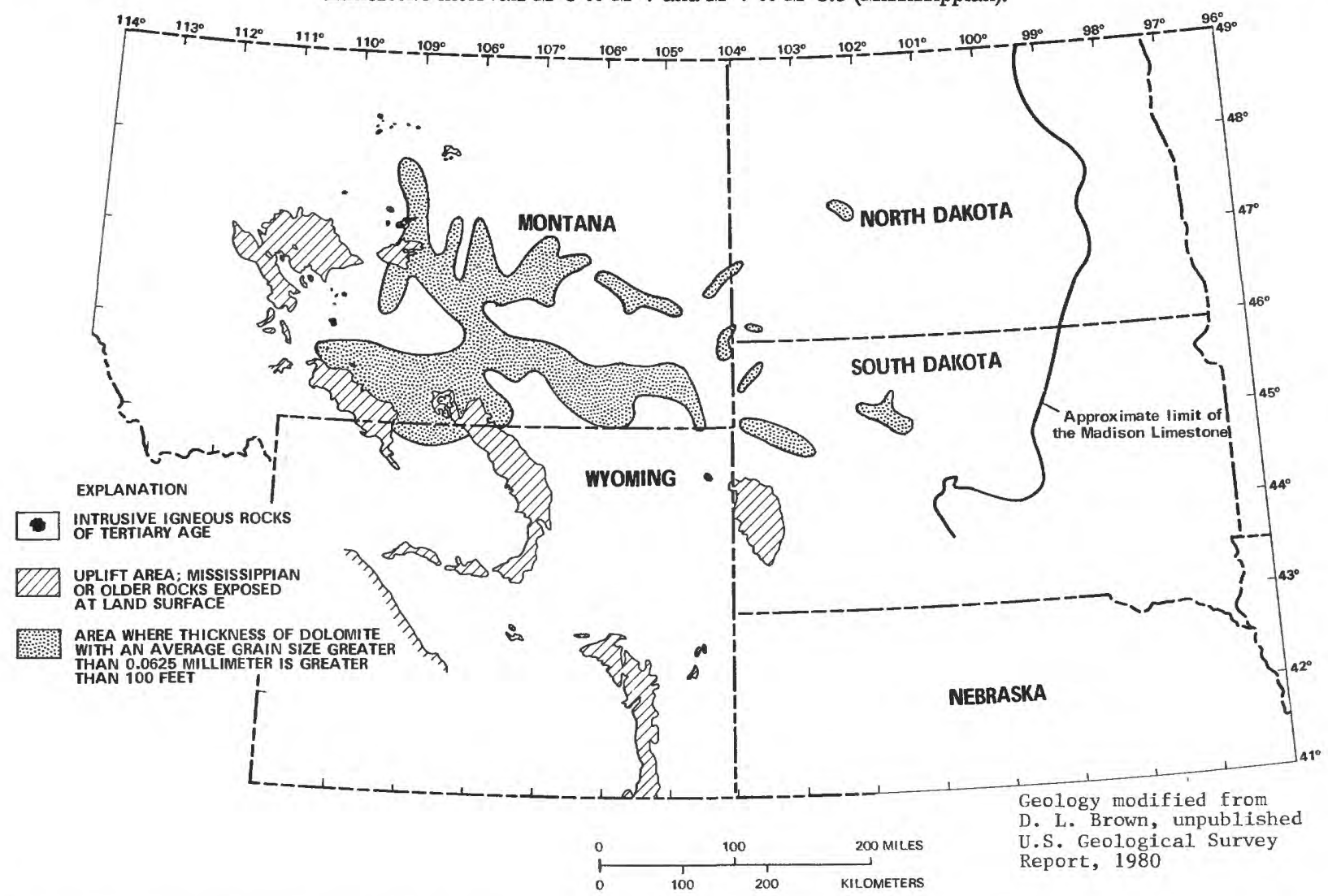

FiguRE 11. - Areas where dolomite with an average grain size greater than $0.0625 \mathrm{~mm}$ is more than $100 \mathrm{ft}$ thick in the Madison Limestone interval M-7 to M-8.5 (Mississippian). 


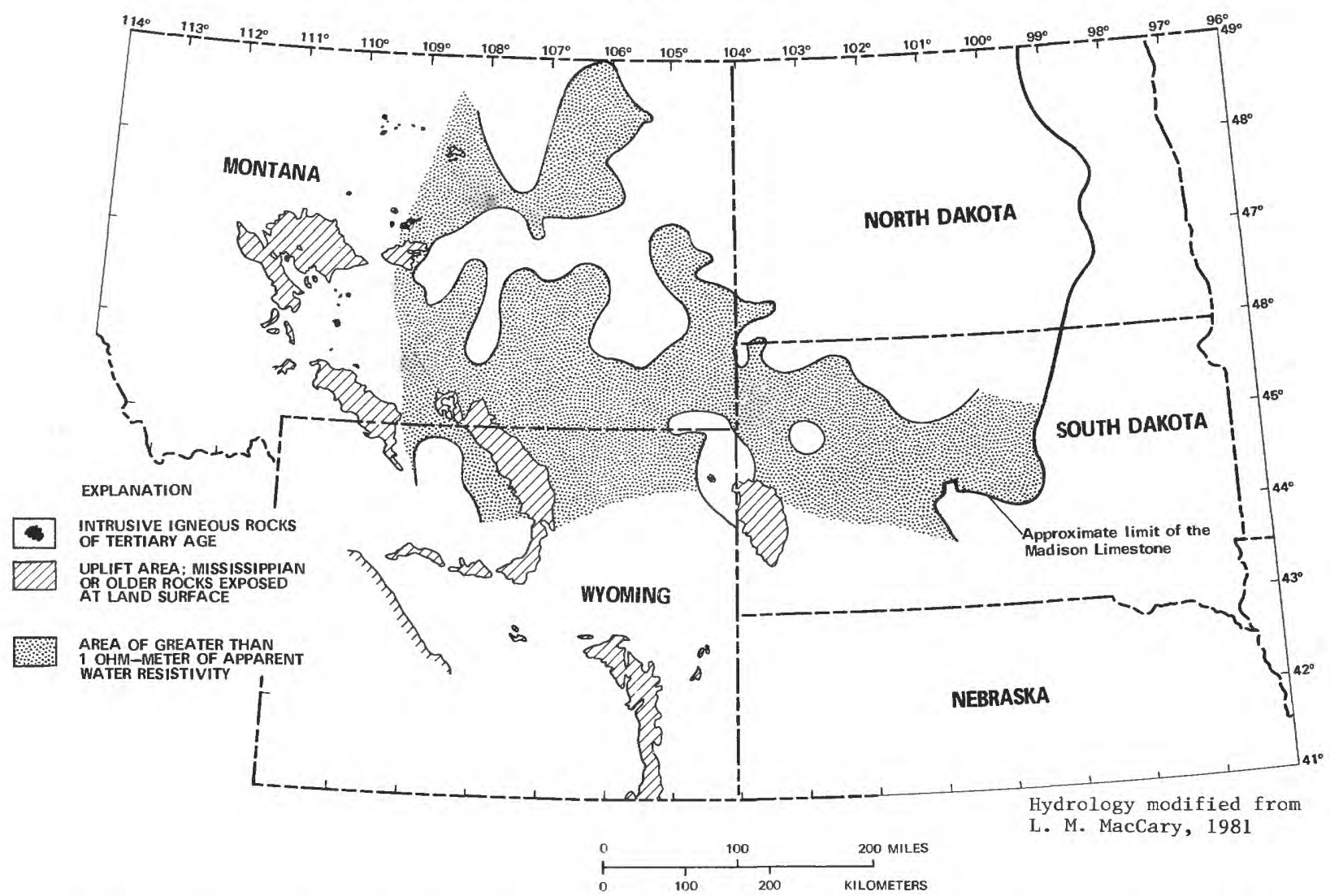

FIGURE 12. - Areas of greater than 1 ohm-meter of apparent water resistivity (Rwa) in the Madison Limestone interval M-7 to M-8.5 (Mississippian).

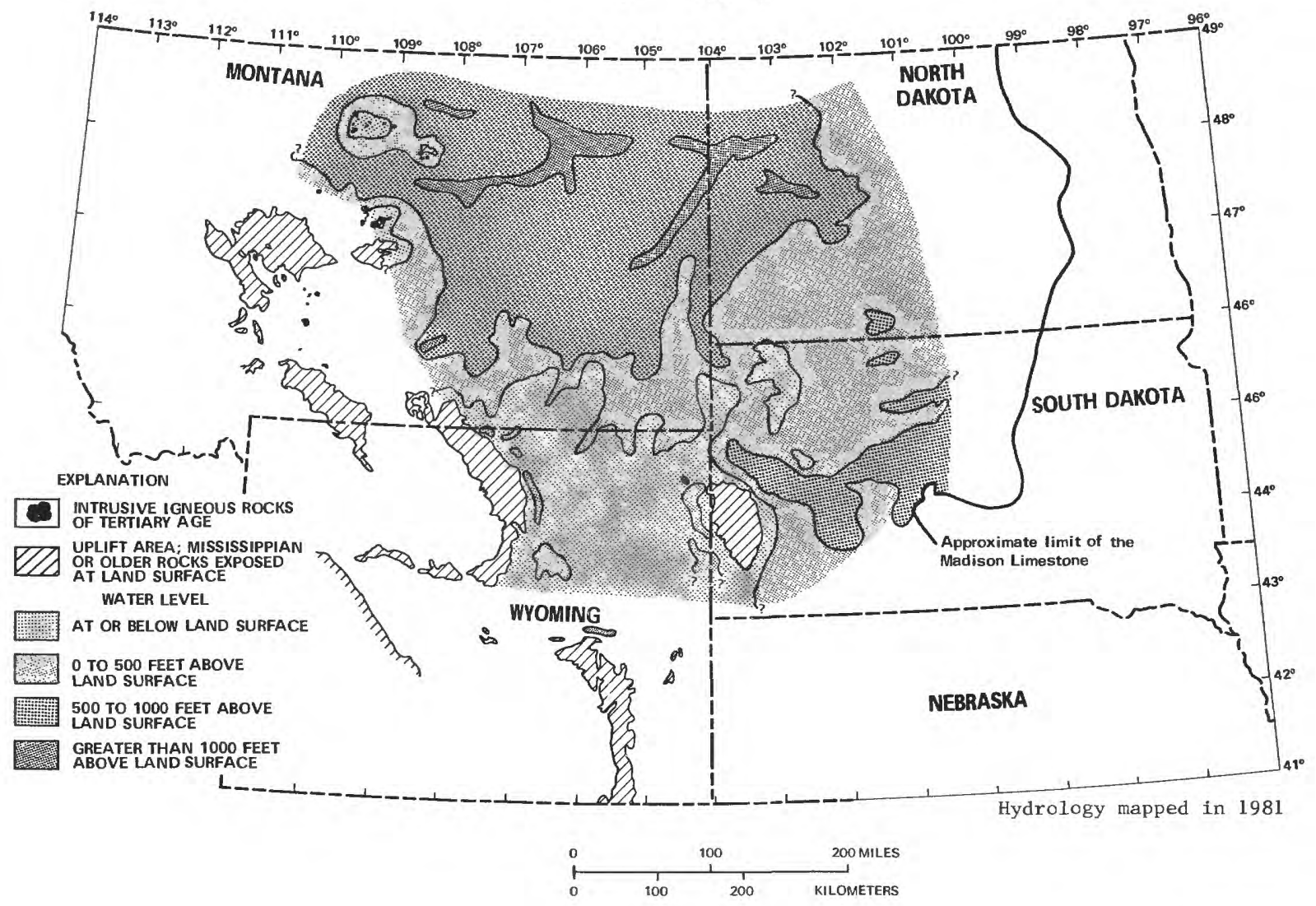

FIGURE 13. - Height to which water will rise in wells completed in the Madison Limestone (Mississippian). 


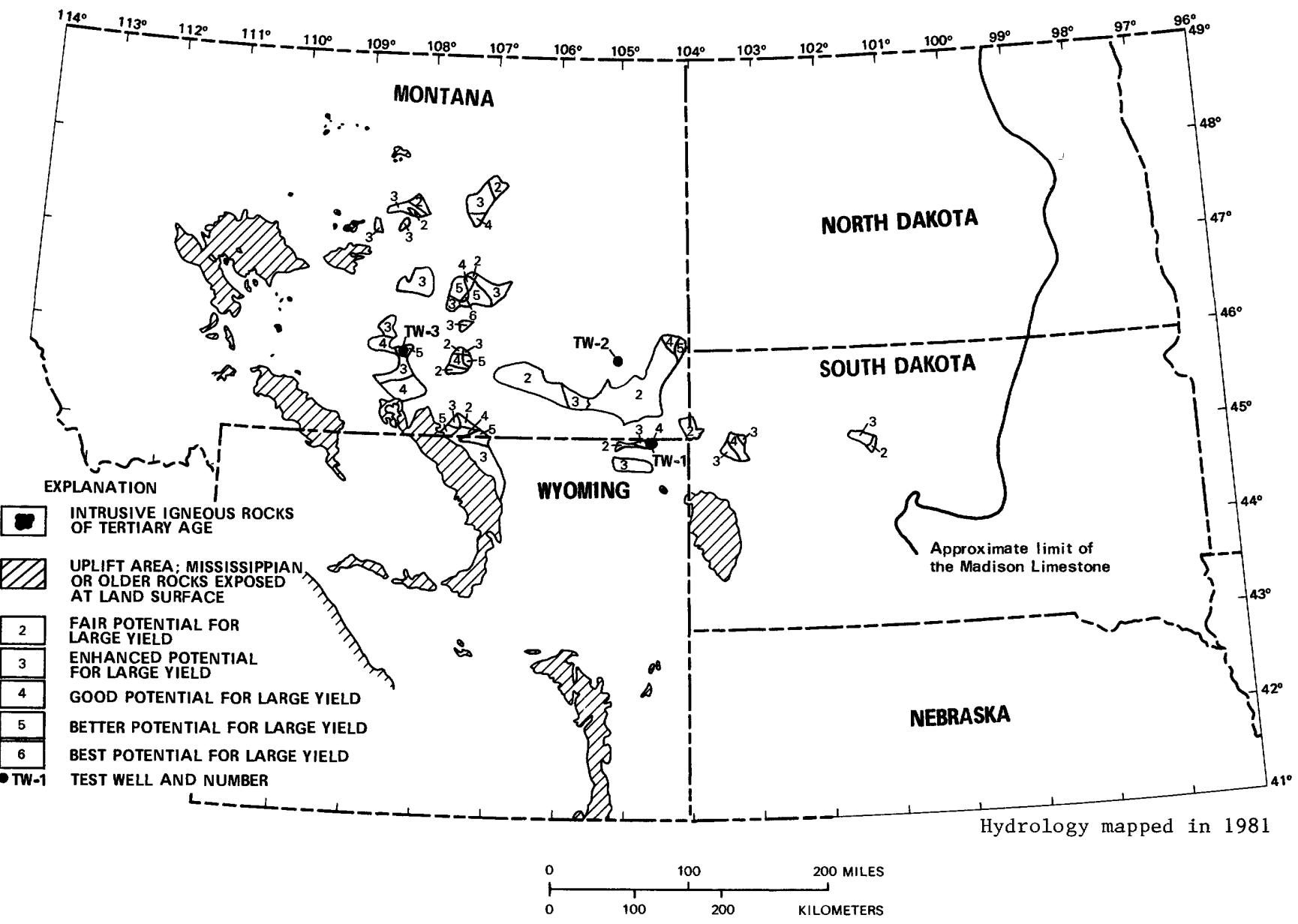

FIGURE 14. - Potentially favorable areas for wells yielding more than $500 \mathrm{gal} / \mathrm{min}$ from both the Red River Formation (Ordovician) and the Madison Limestone (Mississippian).

\section{REFERENCES CITED}

Blankennagel, R. K., Howells, L. W., Miller, W. R., and Hansen, C. V., 1979, Preliminary data for Madison Limestone test well 3, NW1/4SE1/4 sec. 35, T. 2 N., R. 27 E., Yellowstone County, Montana: U.S. Geological Survey Open-File Report 79-745, 186 p.

Blankennagel, R. K., Miller, W. R., Brown, D. L., and Cushing, E. M., 1977, Report on preliminary data for Madison Limestone test well 1, NE $1 / 4$ SE1/4 sec. 15, T. 57 N., R. 65 W., Crook County, Wyoming: U.S. Geological Survey Open-File Report 77-164, 97 p.

Brown, D. L., Blankennagel, R. K., Busby, J. F., and Lee, R. W., 1977, Preliminary data for Madison Limestone test well 2, $\mathrm{NE}^{1 / 4} \mathrm{SE}^{1 / 4}$ sec. 18, T. 1 N., R. 54 E., Custer County, Montana: U.S. Geological Survey Open-File Report 77-863, 135 p.

MacCary, L. M., 1981, Apparent water resistivity, porosity and ground-water temperature of the Madison Limestone and underlying rocks in parts of Montana, North Dakota, South Dakota, and Wyoming: U.S. Geological Survey Open-File Report 81-269. 35 p.
Miller, W. R., and Strausz, S. A., 1980a, Preliminary map showing freshwater heads for the Red River Formation, Bighorn Dolomite, and equivalent rocks of Ordovician age in the Northern Great Plains of Montana, North and South Dakota, and Wyoming: U.S. Geological Survey Open-File Report 80-730, scale 1:1,000,000, 1 sheet.

1980b, Preliminary map showing freshwater heads for the Mission Canyon and Lodgepole Limestones and equivalent rocks of Mississippian age in the Northern Great Plains of Montana, North and South Dakota, and Wyoming: U.S. Geological Survey OpenFile Report 80-879, scale 1:1,000.000, 1 sheet.

Peterson, J. A., 1981, Stratigraphy and sedimentary facies of the Madison Limestone and associated rocks in parts of Montana, North Dakota, South Dakota, Wyoming, and Nebraska: U.S. Geological Survey Open-File Report 81-642, 83 p.

Thayer, P. A., 1981, Petrology and petrography for U.S. Geological Survey test wells 1, 2, and 3 in the Madison Limestone in Montana and Wyoming: U.S. Geological Survey Open-File Report 81-221, $79 \mathrm{p}$. 